\title{
ANALISIS KAPASITAS SALURAN DRAINASE TAMAN CIBODAS TANGERANG
}

\author{
Tirto Wijaya Supiono ${ }^{1}$, Arianti Sutandi ${ }^{2}$, dan Vittorio Kurniawan ${ }^{3}$ \\ ${ }^{1}$ Program Studi Sarjana Teknik Sipil, Universitas Tarumanagara, Jl. Letjen S. Parman No.1 Jakarta \\ Tirto.325160199@stu.untar.ac.id \\ ${ }^{2}$ Program Studi Sarjana Teknik Sipil, Universitas Tarumanagara, Jl. Letjen S. Parman No.1 Jakarta \\ Ariantis@ft.untar.ac.id \\ ${ }^{3}$ Jurusan Studi Sarjana Teknik Sipil, Universitas Tarumanagara, Jl. Letjen S. Parman No.1 Jakarta \\ Vkurniawan@ft.untar.ac.id
}

Masuk: 11-01-2021, revisi: 28-01-2021, diterima untuk diterbitkan: 31-03-2021

\begin{abstract}
Flood is a natural disaster which is caused by various factors and causes many losses. In Cibodas Park, Tangerang, especially Sangiang Jaya Village, it is recorded that it experiences flooding almost every year. This study aims to determine the factors that cause flooding in the area under study and provide a solution. The analysis carried out includes secondary and tertiary channels, which will be calculated by the Manning method to determine the discharge value of each channel, and then will be compared with the discharge value due to the maximum rainfall that occurs. Based on the calculation 36 of the 137 channels reviewed were not able to accommodate the discharge from rainfall that occurred during the 2 year return period. After analyzing it, it can be concluded that the flood in Taman Cibodas Tangerang, especially Sangiang Jaya Village, was caused by the lack of capacity of the existing channel to accommodate the discharge caused by the maximum rainfall. The solution for this is to redesign the existing channel, namely increasing the width and depth of the unsafe channel, as well as routine maintenance of the existing channel.
\end{abstract}

Key words: flood; drainage; rainfall.

\begin{abstract}
ABSTRAK
Banjir adalah sebuah bencana alam yang disebabkan oleh berbagai faktor-faktor dan menimbulkan banyak kerugian. Di Taman Cibodas Tangerang khususnya Kelurahan Sangiang Jaya tercatat mengalami banjir hampir pada setiap tahunnya. Penelitian ini bertujuan untuk mengetahui faktor penyebab terjadinya banjir pada daerah yang diteliti serta memberikan solusinya. Analisis yang dilakukan mencakup saluran sekunder dan tersier, yang akan dihitung dengan metode Manning untuk mengetahui nilai debit dari setiap saluran, dan kemudian akan dibandingkan dengan nilai debit akibat curah hujan maksimum yang terjadi. Berdasarkan perhitungan 36 dari 137 saluran yang ditinjau tidak mampu menampung debit dari curah hujan yang terjadi selama periode ulang 2 tahun. Setelah dianalisis dapat disimpulkan bahwa banjir di Taman Cibodas Tangerang khususnya Kelurahan Sangiang Jaya disebabkan oleh kurangnya kapasitas saluran eksisting untuk menampung debit yang disebabkan oleh curah hujan maksimum. Solusi untuk hal tersebut adalah melakukan desain ulang pada saluran yang ada yaitu memperbesar ukuran lebar dan kedalaman saluran yang tidak aman, serta pemeliharaan saluran yang ada secara rutin.
\end{abstract}

Kata kunci : banjir; drainase; curah hujan.

\section{PENDAHULUAN}

Taman Cibodas Tangerang yang terletak di Kelurahan Sangiang Jaya, Kota Tangerang, Indonesia. Taman Cibodas Tangerang ini berbatasan dengan Kecamatan Karawaci dibagian Selatan berbatasan dengan Kecamatan Kelapa Dua, disebelah Barat berbatasan dengan Kecamatan Cibodas, Kecamatan Jati Uwung dan Kecamatan Kelapa Dua. Sedangkan dibagian timur berbatasan dengan Kecamatan Karawaci dan Kecamatan Pinang. (Badan Pusat Statistik Kota Tangerang). Daerah Taman Cibodas merupakan sebuah daerah pemukiman dan objek perekonomian. Namun Taman Cibodas ini terkenal di Kota Tangerang sebagai daerah dengan seringnya terkena genangan air dalam jangka waktu yang cukup lama dari tahun ke tahun pasti ada kasus banjir terjadi. Gambar dibawah ini menunjukan banjir yang terjadi di Taman Cibodas Tangerang pada 2 Januari 2020. 


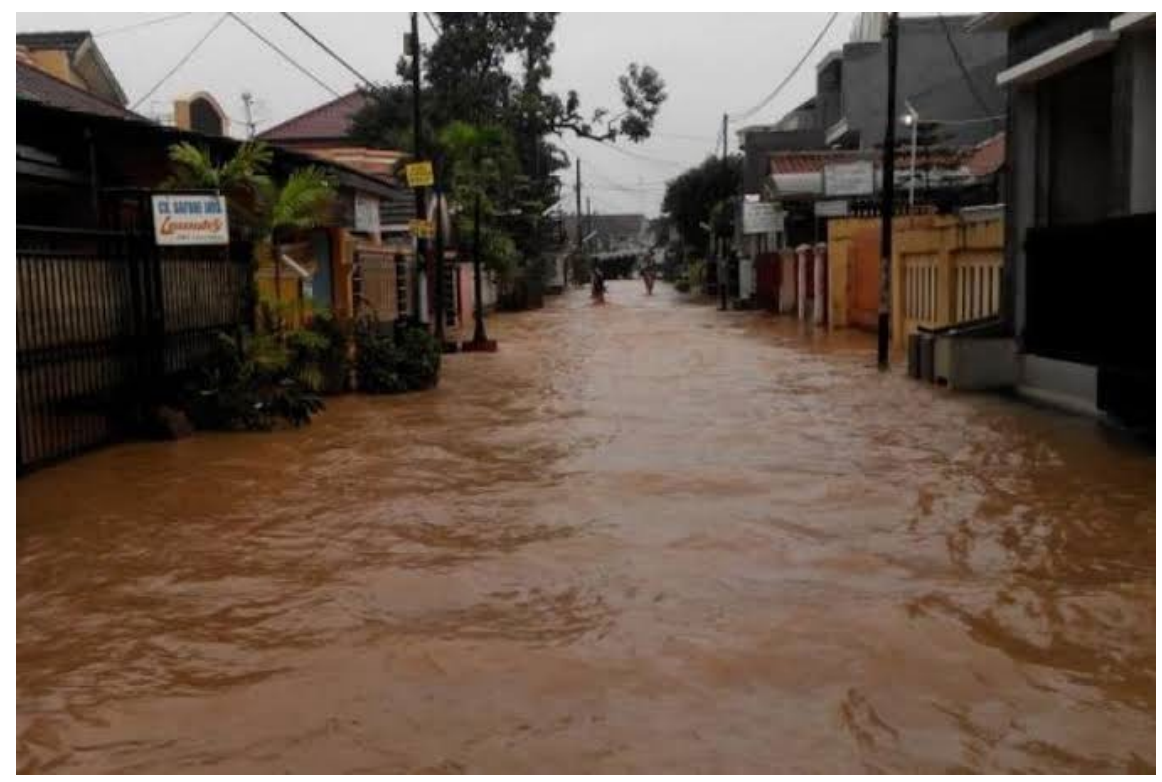

Gambar.1 Banjir Taman Cibodas Tangerang (NKRI Post)

Tujuan dari penelitian ini adalah :

1. Mengetahui kapasitas eksisting saluran.

2. Mengetahui apa saja yang harus dilakukan untuk mencegah bajir yang sama terulang.

Berdasarkan Dinas Pekerjaan Umum dan Penataan Ruang Kota Tangerang titik genangan air yang ada di Taman Cibodas Khususnya Kelurahan Sangiang jaya dapat dilihat pada area yang di beri blok warna ungu pada Gambar 2.

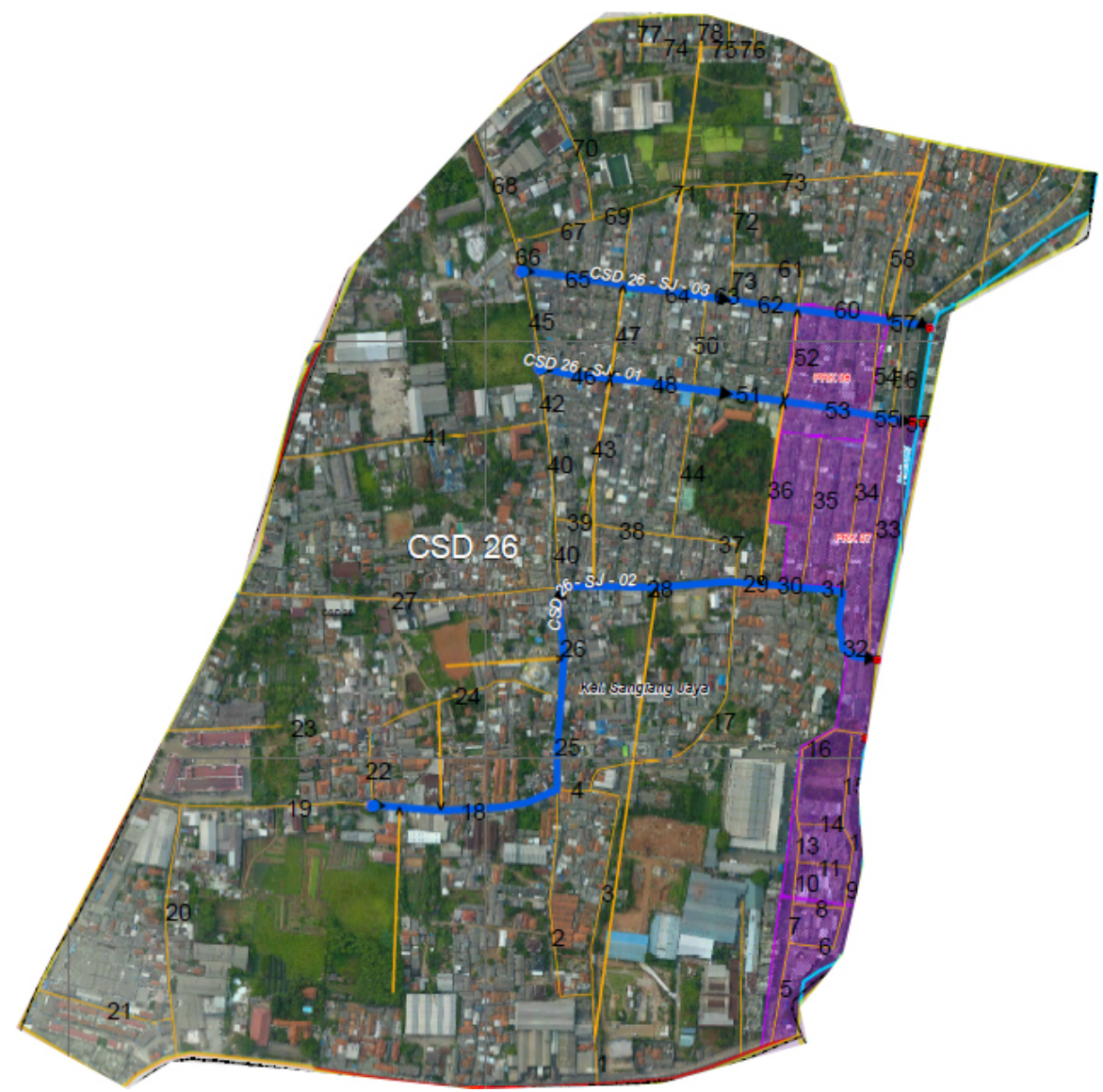

Gambar 2. Sebaran Titik banjir Kelurahan Sangiang Jaya (Dinas Pekerjaan Umum dan Penataan Ruang Kota Tangerang) 


\section{Uji distribusi}

Jenis sebaran fungsi distribusi yang akan digunakan pada untuk uji kecocokan adalah metode pengujian dan dengan confidence interval tertentu dapat menggunakan Metode Chi-Square dan Metode Kolmogorov-Smirnov sebagai berikut. (SNI 2415:2016):

\section{Chi-Square}

Metode ini mengacuh pada besar nilai kuadrat perbedaan antara pengamatan dan teoritis, yang kemudian dibagi dalam kelompok kelas. Uji kecocokan dihitung dengan Persamaan 1.

$$
\frac{k}{X(i=1)}=\frac{(0 i-E i)^{2}}{E i}
$$

dengan $X \frac{k}{n}=$ parameter Chi-Square terhitung, $\mathrm{k}=$ jumlah sub kelompok, $\mathrm{Oi}=$ jumlah nilai pengamatan pada sub kelompok ke I, Ei = jumlah nilai teoritis pada sub kelompok ke i. Jika hasil $X \frac{k}{n}$ besar, menunjukan bahwa distribusi yang dipilih tidak cocok, tetapi uji ini dapat memberikan hasil yang baik jika mempunyai data yang panjang.

\section{Kolmogorov-Smirnof}

Uji kecocokan ini adalah uji kecocokan "non parametric" kareana tidak mengikuti distribusi tertentu. Metode ini menghitung besarnya jarak maksimum secara vertical antara pengamatan dan teoritis dari distribusi sampel. Uji kecocokan dihitung dengan Persamaan 2.

$$
D n=\max |\mathrm{P}(\mathrm{x})-\mathrm{Po}(\mathrm{x})|
$$

dengan $\mathrm{Dn}=$ jarak maksimum antara pengamat dan teoritis, $\mathrm{P}(\mathrm{x})=$ probabilitas dari sampel data, dan $\mathrm{Po}(\mathrm{x})=$ probabilitas dari teoritis. Distribusi dikatakan cocok jika nilai Dn $<$ D kritisnya pada derajat kepercayaan yang diinginkan.

\section{Hujan rencana}

Ada empat jenis distribusi yang banyak digunakan dalam menghitung curah hujan rencana (Upono and Kusumawardani), yaitu :

\section{Distribusi Normal}

Persamaan distribusi normal adalah :

$$
\mathrm{Xt}=\overline{\mathrm{X}}+\mathrm{z} \cdot \mathrm{Sx}
$$

dengan $X_{t}=$ curah hujan rencana $(\mathrm{mm} / \mathrm{hari}), \overline{\mathrm{X}}=$ curah hujan maksimum rata-rata $(\mathrm{mm} / \mathrm{hari}), \mathrm{Sx}=$ standar deviasi, dan $\mathrm{z}=$ factor frekuensi.

\section{Distribusi Log Normal}

Persamaan distribusi Log Normal adalah :

$$
\operatorname{LogXt}=\bar{X}+\text { Kt. Sx }
$$

dengan $X_{t}=$ curah hujan rencana $(\mathrm{mm} / \mathrm{hari}), \overline{\mathrm{x}}=$ curah hujan maksimum rata-rata $(\mathrm{mm} / \mathrm{hari}), \mathrm{Sx}=$ standar deviasi, dan $\mathrm{Kt}=$ standar variable untuk periode ulang tahun.

\section{Distribusi Log Pearson III}

Persamaan distribusi Log Pearson III adalah :

$$
\log \overline{\mathrm{X}}=\frac{\sum_{\mathrm{i}=1}^{\mathrm{n}} \log \left(\mathrm{X}_{\mathrm{i}}\right)}{\mathrm{n}}
$$

dengan $X_{i}=$ nilai curah hujan ( $\mathrm{mm} /$ hari), $\mathrm{n}=$ jumlah data, dan $\log \overline{\mathrm{x}}=$ harga rata-rata logaritmik (mm/hari).

4. Gumbel

Persamaan distribusi gumbel adalah :

$$
\mathrm{X}_{\mathrm{t}}=\overline{\mathrm{x}}+\frac{\left(\mathrm{Y}_{\mathrm{t}}-\mathrm{Y}_{\mathrm{n}}\right)}{\mathrm{S}_{\mathrm{n}}} \times \mathrm{S}_{\mathrm{x}}
$$

dengan $X_{t}=$ nilai curah hujan rencana $(\mathrm{mm} / \mathrm{hari}), \overline{\mathrm{x}}=$ curah hujan maksimum rata-rata $(\mathrm{mm} / \mathrm{hari}), \mathrm{Sx}=$ standar deviasi, $\mathrm{Y}_{\mathrm{t}}=$ reduced variable, $\mathrm{Y}_{\mathrm{n}}=$ reduced mean, $\mathrm{S}_{\mathrm{n}}=$ reduced standard deviation . 


\section{Intensitas hujan}

Intensitas hujan adalah besaran ketinggian hujan yang ditetapkan sebagai harga perencanaan yang memperhatikan periode ulang yang dihitung dengan metode yang lazim dalam analisis hidrologi (SNI 8456:2017).

Data curah hujan yang ada dihitung menggunakan metode mononobe pada persamaan 7 .

$$
I=\frac{R_{24}}{24}\left(\frac{24}{t}\right)^{\frac{2}{3}}
$$

dengan $\mathrm{I}=$ intensitas curah hujan ( $\mathrm{mm} /$ hari), $\mathrm{t}=$ lamanya curah hujan (jam), dan $\mathrm{R}_{24}=$ curah hujan maksimum dalam $24 \mathrm{jam}(\mathrm{mm})$.

\section{Debit rancangan dengan metode rasional}

Metode ini dapat menggambarkan hubungan antara debit limpasan dengan besar curah hujan secara praktis berlaku untuk luas DAS hingga 5.000 hektar. Dua komponen utama ialah waktu konsentrasi (tc) dan intensitas curah hujan (I). Persamaan menurut (SNI 2415:2016) yang digunakan:

$$
\mathrm{Qp}=0,00278 \text { C.I.A }
$$

dengan Qp = Debit puncak $\left(\mathrm{m}^{3} / \mathrm{s}\right), \mathrm{C}=$ koefisien limpasan, $\mathrm{I}=$ intensitas hujan $(\mathrm{mm} / \mathrm{jam})$, dan $\mathrm{A}=$ Luas daerah aliran (Ha).

\section{METODE PENELITIAN}

\section{Pengumpulan data}

Data-data yang diperlukan terdiri dari

1. Peta Sebaran Titik Banjir di Kelurahan Sangiang Jaya, khususnya Taman Cibodas Tangerang dari Dinas PUPR Kota Tangerang.

2. Data Curah Hujan Harian Maksimum stasiun Geofisika Tangerang selama 10 tahun dari Badan Meteorologi Klimatologi dan Geofisika.

3. Peta Jaringan Drainase di Kelurahan Sangiang Jaya, khususnya Taman Cibodas Tangerang dari Dinas PUPR Kota Tangerang.

4. Spesifikasi saluran eksisting di Kelurahan Sangiang Jaya, khususnya Taman Cibodas Tangerang dari Dinas PUPR Kota Tangerang.

5. Peta Topografi Keluarahan Sangiang Jaya, khususnya Taman Cibodas Tangerang dari Dinas Pertanahan Kota Tangerang.

\section{Pengolahan data}

Berikut adalah langka-langkah pengolahan data yang dilakukan dalam analisis pada penelitian ini :

1. Menganalisa curah hujan yaitu dengan mengambil data curah hujan maksimum harian setiap tahun.

2. Melakukan pengujian kecocokan fungsi distribusi dengan menggunakan metode Chi-Square dan Kolmogorov-Smirnov.

3. Melakukan perhitungan frekuensi curah hujan dengan distribusi yang sudah diuji dengan pengujian kecocokan fungsi distribusi.

4. Menghitung kapasitas saluran drainase eksisting.

5. Melakukan pemodelan terhadap saluran eksisting dengan aplikasi HEC-RAS.

6. Melakukan perhitungan intensitas hujan dengan metode Mononobe.

7. Menentukan daerah tangkapan air dari masing-masing saluran.

8. Menghitung debit limpasan dengan metode Rasional.

9. Menganalisis apakah debit saluran eksisting mampu menampung debit limpasan dengan metode Rasional atau tidak, jika tidak maka perlu direncanakan saluran drainase baru.

10. Menganalisis saluran drainase rencana.

11. Melakukan pemodelan terhadap saluran rencana dengan aplikasi $H E C-R A S$.

12. Menganalisis topografi dari wilayah yang terdampak banjir.

13. Memberikan kesimpulan terhadap analisa penyebab banjir. 


\section{HASIL DAN PEMBAHASAN}

\section{Perhitungan curah hujan rencana}

Dari data curah hujan harian yang didapatkan dari BMKG Stasiun Geofisika Tangerang, dilakukan pemilihan fungsi distribusi menggunakan metode Chi-Square dan Kolmogorov-Smirnov, dan hasilnya dapat dilihat pada Tabel 1.

Tabel 1. Uji Chi-Square dan Kolmogorov-Smirnov

\begin{tabular}{llllllll}
\hline \multirow{2}{*}{ No } & \multirow{2}{*}{ Distribusi } & \multicolumn{2}{c}{ Chi-Square } & \multirow{2}{*}{ Kesimpulan } & \multicolumn{2}{c}{ Kolmogorov-Smirnov } & \multirow{2}{*}{ Kesimpulan } \\
& & $\mathrm{X}^{2}$ & $\mathrm{X}^{2} \mathrm{Cr}$ & & Do & Dmax & \\
\hline 1 & Normal & 5,991 & 11 & Tidak Diterima & 0,41 & 0,122209 & Diterima \\
2 & Log Normal & 5,991 & 4 & Diterima & 0,41 & 0,1358 & Diterima \\
3 & Log Pearson III & 5,991 & 3 & Diterima & 0,41 & 0,1268 & Diterima \\
4 & Gumbel & 5,991 & 5 & Diterima & 0,41 & 0,4562 & Tidak Diterima \\
\hline
\end{tabular}

Distribusi yang akan digunakan adalah distribusi Log Pearson III, karena memiliki nilai kritis paling kecil.

Hasil perhitungan curah hujan rencana dengan metode Log Pearson III dapat dilihat pada Tabel 2.

Tabel 2. Curah hujan rencana

\begin{tabular}{cccc}
\hline Tahun & $\mathrm{K}$ & $\log \mathrm{Rr}$ & $\mathrm{Rr}(\mathrm{mm})$ \\
\hline 2 & 0,026 & 1,9872 & 97,1918 \\
5 & 0,843 & 2,0683 & 117,070 \\
10 & 1,263 & 2,1099 & 128,821 \\
20 & 1,565 & 2,1398 & 137,993 \\
\hline
\end{tabular}

\section{Analisis saluran eksisting}

Data saluran yang sudah didapat dari Dinas PUPR Kota Tangerang, lalu dianalisis untuk mengetahui nilai debit dari setiap saluran yang ada dengan metode manning dan debit rancangan menggunakan metode rasional. Hasil perhitungan analisis saluran eksisting dapat dilihat pada Tabel 3 sebagai berikut.

Tabel 3. Analisis saluran eksisting

\begin{tabular}{llccccccc}
\hline No & Posisi & $\begin{array}{c}\text { Panjang } \\
(\mathrm{m})\end{array}$ & $\begin{array}{c}\text { Lebar } \\
(\mathrm{m})\end{array}$ & $\begin{array}{c}\text { Kedalaman } \\
(\mathrm{m})\end{array}$ & $\mathrm{V}(\mathrm{m} / \mathrm{s})$ & $\begin{array}{c}\text { Debit } \\
\text { Limpasan } \\
\left(\mathrm{m}^{3} / \mathrm{s}\right)\end{array}$ & $\begin{array}{c}\text { Debit } \\
\text { Eksisting } \\
\left(\mathrm{m}^{3} / \mathrm{s}\right)\end{array}$ & Keterangan \\
\hline \multirow{2}{*}{1} & Kiri & 107,101 & 0,4 & 0,4 & 0,4570 & 0,0281 & 0,0183 & MEMENUHI \\
& Kanan & 107,101 & 0,4 & 0,4 & 0,4570 & 0,0325 & 0,0212 & MEMENUHI \\
2 & Kiri & 286,667 & 0,4 & 0,4 & 0,6640 & 0,0456 & 0,0342 & MEMENUHI \\
& Kanan & 286,667 & 0,4 & 0,4 & 0,6640 & 0,0470 & 0,0352 & MEMENUHI \\
3 & Kiri & 276,719 & 0,4 & 0,4 & 0,2850 & 0,0184 & 0,0184 & MEMENUHI \\
& Kanan & 276,719 & 0,4 & 0,4 & 0,2850 & 0,0225 & 0,0225 & MEMENUHI \\
& Kiri & 39,321 & 0,4 & 0,4 & 0,5493 & 0,1264 & 0,0608 & TIDAK MEMENUHI \\
& Kanan & 39,321 & 0,4 & 0,4 & 0,5493 & 0,1067 & 0,1416 & TIDAK MEMENUHI \\
5 & Kiri & 122,765 & 0,4 & 0,4 & 0,6094 & 0,1322 & 0,1722 & TIDAK MEMENUHI \\
& Kanan & 122,765 & 0,4 & 0,4 & 0,6094 & 0,0171 & 0,0222 & MEMENUHI \\
6 & Kiri & 102,397 & 0,4 & 0,4 & 0,5801 & 0,0133 & 0,0153 & MEMENUHI \\
& Kanan & 102,397 & 0,4 & 0,4 & 0,5801 & 0,0277 & 0,0319 & MEMENUHI \\
7 & Kiri & 47,104 & 0,4 & 0,4 & 0,4936 & 0,2551 & 0,2555 & TIDAK MEMENUHI \\
& Kanan & 47,104 & 0,4 & 0,4 & 0,4936 & 0,0360 & 0,0361 & MEMENUHI \\
8 & Kiri & 61,318 & 0,4 & 0,4 & 0,4309 & 0,0156 & 0,0167 & MEMENUHI \\
& Kanan & 61,318 & 0,4 & 0,4 & 0,4309 & 0,0169 & 0,0181 & MEMENUHI \\
9 & Kiri & 50,363 & 0,4 & 0,4 & 0,5386 & 0,0139 & 0,0139 & MEMENUHI \\
& Kanan & 50,363 & 0,4 & 0,4 & 0,5386 & 0,0139 & 0,0139 & MEMENUHI \\
10 & Kiri & 50,786 & 0,4 & 0,4 & 0,4695 & 0,1871 & 0,1894 & TIDAK MEMENUHI \\
& Kanan & 50,786 & 0,4 & 0,4 & 0,4695 & 0,0988 & 0,1000 & TIDAK MEMENUHI \\
\hline
\end{tabular}


Tabel 3. Analisis saluran eksisting (Lanjutan)

\begin{tabular}{|c|c|c|c|c|c|c|c|c|}
\hline No & Posisi & $\begin{array}{l}\text { Panjang } \\
\text { (m) }\end{array}$ & $\begin{array}{l}\text { Lebar } \\
(\mathrm{m})\end{array}$ & $\begin{array}{l}\text { Kedalaman } \\
\text { (m) }\end{array}$ & $\mathrm{V}(\mathrm{m} / \mathrm{s})$ & $\begin{array}{c}\text { Debit } \\
\text { Limpasan } \\
\left(\mathrm{m}^{3} / \mathrm{s}\right)\end{array}$ & $\begin{array}{c}\text { Debit } \\
\text { Eksisting } \\
\left(\mathrm{m}^{3} / \mathrm{s}\right)\end{array}$ & Keterangan \\
\hline \multirow{2}{*}{11} & Kiri & 63,408 & 0,4 & 0,4 & 0,5998 & 0,0275 & 0,0278 & MEMENUHI \\
\hline & Kanan & 63,408 & 0,4 & 0,4 & 0,5998 & 0,0275 & 0,0278 & MEMENUHI \\
\hline \multirow{2}{*}{12} & Kiri & 53,454 & 0,4 & 0,4 & 0,4570 & 0,0091 & 0,0093 & MEMENUHI \\
\hline & Kanan & 53,454 & 0,4 & 0,4 & 0,4570 & 0,0055 & 0,0056 & MEMENUHI \\
\hline \multirow{2}{*}{13} & Kiri & 46,437 & 0,4 & 0,4 & 0,7064 & 0,2932 & 0,2409 & TIDAK MEMENUHI \\
\hline & Kanan & 46,437 & 0,4 & 0,4 & 0,7064 & 0,1479 & 0,1215 & TIDAK MEMENUHI \\
\hline \multirow{2}{*}{14} & Kiri & 52,625 & 0,4 & 0,4 & 0,6640 & 0,0274 & 0,0246 & MEMENUHI \\
\hline & Kanan & 52,625 & 0,4 & 0,4 & 0,6640 & 0,0181 & 0,0162 & MEMENUHI \\
\hline \multirow{2}{*}{15} & Kiri & 108,525 & 0,4 & 0,4 & 0,7306 & 0,0320 & 0,0315 & MEMENUHI \\
\hline & Kanan & 108,525 & 0,4 & 0,4 & 0,7306 & 0,0182 & 0,0179 & MEMENUHI \\
\hline \multirow{2}{*}{16} & Kiri & 202,375 & 0,4 & 0,4 & 0,5801 & 0,2273 & 0,3083 & TIDAK MEMENUHI \\
\hline & Kanan & 202,375 & 0,4 & 0,4 & 0,5801 & 0,1374 & 0,1864 & TIDAK MEMENUHI \\
\hline \multirow{2}{*}{17} & Kiri & 355,409 & 0,4 & 0,4 & 0,5166 & 0,2432 & 0,2129 & TIDAK MEMENUHI \\
\hline & Kanan & 355,409 & 0,4 & 0,4 & 0,5166 & 0,2487 & 0,2177 & TIDAK MEMENUHI \\
\hline 18 & Kanan & 224,328 & 1,2 & 1,2 & 2,3256 & 0,4898 & 0,5549 & MEMENUHI \\
\hline \multirow{2}{*}{19} & Kiri & 231,796 & 0,4 & 0,4 & 0,8618 & 0,1960 & 0,1960 & TIDAK MEMENUHI \\
\hline & Kanan & 231,796 & 0,4 & 0,4 & 0,8618 & 0,3077 & 0,3077 & TIDAK MEMENUHI \\
\hline \multirow{2}{*}{20} & Kiri & 256,199 & 0,4 & 0,4 & 0,6981 & 0,2150 & 0,2140 & TIDAK MEMENUHI \\
\hline & Kanan & 256,199 & 0,4 & 0,4 & 0,6981 & 0,2523 & 0,2510 & TIDAK MEMENUHI \\
\hline \multirow{2}{*}{21} & Kiri & 169,302 & 0,4 & 0,4 & 0,1866 & 0,0724 & 0,0908 & TIDAK MEMENUHI \\
\hline & Kanan & 169,302 & 0,4 & 0,4 & 0,1866 & 0,0499 & 0,0626 & TIDAK MEMENUHI \\
\hline \multirow{2}{*}{22} & Kiri & 99,596 & 0,4 & 0,4 & 0,9931 & 0,0773 & 0,0773 & MEMENUHI \\
\hline & Kanan & 99,596 & 0,4 & 0,4 & 0,9931 & 0,0228 & 0,0228 & MEMENUHI \\
\hline \multirow{2}{*}{23} & Kiri & 268,015 & 0,4 & 0,4 & 0,5801 & 0,0436 & 0,0436 & MEMENUHI \\
\hline & Kanan & 268,015 & 0,4 & 0,4 & 0,5801 & 0,0270 & 0,0270 & MEMENUHI \\
\hline \multirow{2}{*}{24} & Kiri & 229,183 & 0,4 & 0,4 & 0,7064 & 0,0461 & 0,0506 & MEMENUHI \\
\hline & Kanan & 229,183 & 0,4 & 0,4 & 0,7064 & 0,1442 & 0,1584 & TIDAK MEMENUHI \\
\hline 25 & Kanan & 110,616 & 1,2 & 1,2 & 1,5601 & 0,5405 & 0,5457 & MEMENUHI \\
\hline 26 & Kanan & 132,538 & 1,2 & 1,2 & 1,2196 & 0,0947 & 0,0853 & MEMENUHI \\
\hline \multirow{2}{*}{27} & Kiri & 393,568 & 0,4 & 0,4 & 0,5597 & 0,2236 & 0,2236 & TIDAK MEMENUHI \\
\hline & Kanan & 393,568 & 0,4 & 0,4 & 0,5597 & 0,1683 & 0,1683 & TIDAK MEMENUHI \\
\hline 28 & Kanan & 212,366 & 1,2 & 1,2 & 1,8929 & 0,8455 & 1,0717 & MEMENUHI \\
\hline 29 & Kanan & 29,761 & 1,2 & 1,2 & 3,2162 & 1,6948 & 1,1220 & MEMENUHI \\
\hline 30 & Kanan & 48327 & 12 & 12 & $\begin{array}{l}1,7168 \\
17168\end{array}$ & 10308 & 11561 & MFMFNIHI \\
\hline 31 & Kanan & 51,615 & 1,2 & 1,2 & 4,6074 & 2,2405 & 1,2545 & MEMENUHI \\
\hline 32 & Kanan & 101,124 & 1,2 & 1,2 & 1,7442 & 1,3634 & 1,3634 & MEMENUHI \\
\hline & Kiri & 289,567 & 0,4 & 0,4 & 0,6281 & 0,0286 & 0,0286 & MEMENUHI \\
\hline 33 & Kanan & 289,567 & 0,4 & 0,4 & 0,6281 & 0,0393 & 0,0393 & MEMENUHI \\
\hline & Kiri & 216,179 & 0,4 & 0,4 & 0,8883 & 0,0344 & 0,0344 & MEMENUHI \\
\hline 34 & Kanan & 216,179 & 0,4 & 0,4 & 0,8883 & 0,0573 & 0,0573 & MEMENUHI \\
\hline & Kiri & 218,603 & 0,4 & 0,4 & 0,9267 & 0,0418 & 0,0418 & MEMENUHI \\
\hline 35 & Kanan & 218,603 & 0,4 & 0,4 & 0,9267 & 0,0383 & 0,0383 & MEMENUHI \\
\hline & Kiri & 221,525 & 0,4 & 0,4 & 1,0048 & 0,1001 & 0,1001 & TIDAK MEMENUHI \\
\hline 36 & Kanan & 221,525 & 0,4 & 0,4 & 1,0048 & 0,0415 & 0,0415 & MEMENUHI \\
\hline & Kiri & 124,166 & 0,4 & 0,4 & 0,5597 & 0,0140 & 0,0140 & MEMENUHI \\
\hline 37 & Kanan & 124,166 & 0,4 & 0,4 & 0,5597 & 0,0296 & 0,0296 & MEMENUHI \\
\hline
\end{tabular}


Tabel 3. Analisis saluran eksisting (Lanjutan)

\begin{tabular}{|c|c|c|c|c|c|c|c|c|}
\hline No & Posisi & $\begin{array}{l}\text { Panjang } \\
\text { (m) }\end{array}$ & $\begin{array}{l}\text { Lebar } \\
(\mathrm{m})\end{array}$ & $\begin{array}{l}\text { Kedalaman } \\
(\mathrm{m})\end{array}$ & $\mathrm{V}(\mathrm{m} / \mathrm{s})$ & $\begin{array}{c}\text { Debit } \\
\text { Limpasan } \\
\left(\mathrm{m}^{3} / \mathrm{s}\right)\end{array}$ & $\begin{array}{c}\text { Debit } \\
\text { Eksisting } \\
\left(\mathrm{m}^{3} / \mathrm{s}\right)\end{array}$ & Keterangan \\
\hline \multirow{2}{*}{38} & Kiri & 105,212 & 0,4 & 0,4 & 0,7385 & 0,0372 & 0,0295 & MEMENUHI \\
\hline & Kanan & 105,212 & 0,4 & 0,4 & 0,7385 & 0,0541 & 0,0428 & MEMENUHI \\
\hline \multirow{2}{*}{39} & Kiri & 37,358 & 0,4 & 0,4 & 0,6373 & 0,0217 & 0,0131 & MEMENUHI \\
\hline & Kanan & 37,358 & 0,4 & 0,4 & 0,6373 & 0,0141 & 0,0085 & MEMENUHI \\
\hline \multirow{2}{*}{40} & Kiri & 83,124 & 0,4 & 0,4 & 0,8133 & 0,0609 & 0,0341 & MEMENUHI \\
\hline & Kanan & 83,124 & 0,4 & 0,4 & 0,7916 & 0,0478 & 0,0268 & MEMENUHI \\
\hline \multirow{2}{*}{41} & Kiri & 117,268 & 0,4 & 0,4 & 0,5597 & 0,2280 & 0,2280 & TIDAK MEMENUHI \\
\hline & Kanan & 117,268 & 0,4 & 0,4 & 0,5597 & 0,2751 & 0,2751 & TIDAK MEMENUHI \\
\hline \multirow{2}{*}{42} & Kiri & 321,807 & 0,4 & 0,4 & 0,7064 & 0,0553 & 0,0553 & MEMENUHI \\
\hline & Kanan & 321,807 & 0,4 & 0,4 & 0,7064 & 0,0251 & 0,0251 & MEMENUHI \\
\hline \multirow{2}{*}{43} & Kiri & 63,706 & 0,4 & 0,4 & 0,7385 & 0,1183 & 0,1183 & TIDAK MEMENUHI \\
\hline & Kanan & 63,706 & 0,4 & 0,4 & 0,7385 & 0,0537 & 0,0537 & MEMENUHI \\
\hline \multirow{2}{*}{44} & Kiri & 175,746 & 0,4 & 0,4 & 0,7226 & 0,0553 & 0,0553 & MEMENUHI \\
\hline & Kanan & 175,746 & 0,4 & 0,4 & 0,7226 & 0,0507 & 0,0507 & MEMENUHI \\
\hline \multirow{2}{*}{45} & Kiri & 178,028 & 0,4 & 0,4 & 0,2409 & 0,0176 & 0,0176 & MEMENUHI \\
\hline & Kanan & 178,028 & 0,4 & 0,4 & 0,2409 & 0,0192 & 0,0192 & MEMENUHI \\
\hline 46 & Kiri & 119,561 & 1 & 1 & 2,5478 & 0,7099 & 0,7319 & MEMENUHI \\
\hline \multirow{2}{*}{47} & Kiri & 84,382 & 0,4 & 0,4 & 0,4570 & 0,0439 & 0,0439 & TIDAK MEMENUHI \\
\hline & Kanan & 84,382 & 0,4 & 0,4 & 0,4570 & 0,0369 & 0,0369 & TIDAK MEMENUHI \\
\hline 48 & Kanan & 114,561 & 1 & 1 & 1,7798 & 0,1193 & 0,1369 & MEMENUHI \\
\hline \multirow{2}{*}{49} & Kiri & 100,809 & 0,4 & 0,4 & 0,7768 & 0,0613 & 0,0613 & MEMENUHI \\
\hline & Kanan & 100,809 & 0,4 & 0,4 & 0,7768 & 0,0288 & 0,0288 & MEMENUHI \\
\hline \multirow{2}{*}{50} & Kiri & 112,421 & 0,4 & 0,4 & 0,8482 & 0,0294 & 0,0294 & MEMENUHI \\
\hline & Kanan & 112,421 & 0,4 & 0,4 & 0,8482 & 0,0318 & 0,0318 & MEMENUHI \\
\hline 51 & Kanan & 109,57 & 1 & 1 & 1,1841 & 0,1787 & 0,3056 & MEMENUHI \\
\hline \multirow{2}{*}{52} & Kiri & 111,567 & 0,4 & 0,4 & 0,8550 & 0,0291 & 0,0291 & MEMENUHI \\
\hline & Kanan & 111,567 & 0,4 & 0,4 & 0,8550 & 0,0253 & 0,0253 & MEMENUHI \\
\hline 53 & Kanan & 102,719 & 1 & 1 & 1,9735 & 0,3910 & 0,4423 & MEMENUHI \\
\hline \multirow{2}{*}{54} & Kiri & 114,096 & 0,4 & 0,4 & 0,6898 & 0,0244 & 0,0244 & MEMENUHI \\
\hline & Kanan & 114,096 & 0,4 & 0,4 & 0,6898 & 0,0169 & 0,0169 & MEMENUHI \\
\hline 55 & Kanan & 28,262 & 1 & 1 & 1,7944 & 0,5164 & 0,4587 & MEMENUHI \\
\hline \multirow{2}{*}{56} & Kiri & 115,373 & 0,4 & 0,4 & 0,9990 & 0,0198 & 0,0198 & MEMENUHI \\
\hline & Kanan & 115,373 & 0,4 & 0,4 & 0,9990 & 0,0199 & 0,0199 & MEMENUHI \\
\hline 57 & Kanan & 49,741 & 1 & 1 & 2,0761 & 0,4744 & 0,4744 & MEMENUHI \\
\hline \multirow{2}{*}{58} & Kiri & 29,098 & 0,4 & 0,4 & 0,5493 & 0,0069 & 0,0069 & MEMENUHI \\
\hline & Kanan & 29,098 & 0,4 & 0,4 & 0,5493 & 0,0124 & 0,0124 & MEMENUHI \\
\hline \multirow{2}{*}{59} & Kiri & 180,675 & 0,4 & 0,4 & 0,4031 & 0,0387 & 0,0387 & TIDAK MEMENUHI \\
\hline & Kanan & 180,675 & 0,4 & 0,4 & 0,4031 & 0,1418 & 0,1418 & TIDAK MEMENUHI \\
\hline 60 & Kanan & 99,375 & 1 & 1 & 1,0191 & 0,3838 & 0,6441 & MEMENUHI \\
\hline 61 & Kiri & 132,134 & 0,4 & 0,4 & 0,5900 & 0,1505 & 0,1505 & TIDAK MEMENUHI \\
\hline 01 & Kanan & 132,134 & 0,4 & 0,4 & 0,5900 & 0,0131 & 0,0131 & MEMENUHI \\
\hline 62 & Kanan & 81,787 & 1 & 1 & 0,5582 & 0,3551 & 0,4147 & MEMENUHI \\
\hline 63 & Kanan & 28,983 & 1 & 1 & 1,8513 & 0,4440 & 0,3468 & MEMENUHI \\
\hline 64 & Kanan & 101,313 & 1 & 1 & 2,0126 & 0,2879 & 0,3251 & MEMENUHI \\
\hline
\end{tabular}


Tabel 3. Analisis saluran eksisting (Lanjutan)

\begin{tabular}{|c|c|c|c|c|c|c|c|c|}
\hline No & Posisi & $\begin{array}{l}\text { Panjang } \\
\text { (m) }\end{array}$ & $\begin{array}{l}\text { Lebar } \\
(\mathrm{m})\end{array}$ & $\begin{array}{l}\text { Kedalaman } \\
\text { (m) }\end{array}$ & $\mathrm{V}(\mathrm{m} / \mathrm{s})$ & $\begin{array}{c}\text { Debit } \\
\text { Limpasan } \\
\left(\mathrm{m}^{3} / \mathrm{s}\right)\end{array}$ & $\begin{array}{c}\text { Debit } \\
\text { Eksisting } \\
\left(\mathrm{m}^{3} / \mathrm{s}\right)\end{array}$ & Keterangan \\
\hline 65 & Kanan & 121,727 & 1 & 1 & 2,0636 & 0,1417 & 0,1484 & MEMENUHI \\
\hline \multirow{2}{*}{66} & Kiri & 35,201 & 0,4 & 0,4 & 0,8482 & 0,4703 & 0,3463 & TIDAK MEMENUHI \\
\hline & Kanan & 35,201 & 0,4 & 0,4 & 0,8482 & 0,2942 & 0,2166 & TIDAK MEMENUHI \\
\hline \multirow{2}{*}{67} & Kiri & 97,545 & 0,4 & 0,4 & 0,5998 & 0,1669 & 0,2133 & TIDAK MEMENUHI \\
\hline & Kanan & 97,545 & 0,4 & 0,4 & 0,5998 & 0,1042 & 0,1333 & TIDAK MEMENUHI \\
\hline \multirow{2}{*}{68} & Kiri & 146,783 & 0,4 & 0,4 & 1,5386 & 0,1221 & 0,1221 & MEMENUHI \\
\hline & Kanan & 146,783 & 0,4 & 0,4 & 1,5386 & 0,0630 & 0,0630 & MEMENUHI \\
\hline \multirow{2}{*}{69} & Kiri & 48,686 & 0,4 & 0,4 & 0,4172 & 0,0301 & 0,0301 & MEMENUHI \\
\hline & Kanan & 48,686 & 0,4 & 0,4 & 0,4172 & 0,0285 & 0,0285 & MEMENUHI \\
\hline \multirow{2}{*}{70} & Kiri & 194,135 & 0,4 & 0,4 & 0,8817 & 0,0833 & 0,0833 & TIDAK MEMENUHI \\
\hline & Kanan & 194,135 & 0,4 & 0,4 & 0,8817 & 0,0604 & 0,0604 & MEMENUHI \\
\hline \multirow{2}{*}{71} & Kiri & 131,965 & 0,4 & 0,4 & 0,6640 & 0,0430 & 0,0430 & MEMENUHI \\
\hline & Kanan & 131,965 & 0,4 & 0,4 & 0,6640 & 0,0355 & 0,0355 & MEMENUHI \\
\hline \multirow{2}{*}{72} & Kiri & 97,251 & 0,4 & 0,4 & 0,9077 & 0,0593 & 0,0458 & MEMENUHI \\
\hline & Kanan & 97,251 & 0,4 & 0,4 & 0,9077 & 0,0380 & 0,0293 & MEMENUHI \\
\hline \multirow{2}{*}{73} & Kiri & 41 & 0,4 & 0,4 & 1,0048 & 0,0191 & 0,0130 & MEMENUHI \\
\hline & Kanan & 41 & 0,4 & 0,4 & 1,0048 & 0,0106 & 0,0072 & MEMENUHI \\
\hline \multirow{2}{*}{74} & Kiri & 218,889 & 0,4 & 0,4 & 0,7916 & 0,0553 & 0,0586 & MEMENUHI \\
\hline & Kanan & 218,889 & 0,4 & 0,4 & 0,7916 & 0,0584 & 0,0619 & MEMENUHI \\
\hline \multirow{2}{*}{75} & Kiri & 72,964 & 0,4 & 0,4 & 0,5493 & 0,0046 & 0,0047 & MEMENUHI \\
\hline & Kanan & 72,964 & 0,4 & 0,4 & 0,5493 & 0,0276 & 0,0285 & MEMENUHI \\
\hline \multirow{2}{*}{76} & Kiri & 32,936 & 0,4 & 0,4 & 0,5900 & 0,0025 & 0,0018 & MEMENUHI \\
\hline & Kanan & 32,936 & 0,4 & 0,4 & 0,5900 & 0,0187 & 0,0130 & MEMENUHI \\
\hline \multirow{2}{*}{77} & Kiri & 30,004 & 0,4 & 0,4 & 0,6727 & 0,0204 & 0,0146 & MEMENUHI \\
\hline & Kanan & 30,004 & 0,4 & 0,4 & 0,6727 & 0,0161 & 0,0115 & MEMENUHI \\
\hline \multirow{2}{*}{78} & Kiri & 30,654 & 0,4 & 0,4 & 0,6094 & 0,0176 & 0,0127 & MEMENUHI \\
\hline & Kanan & 30,654 & 0,4 & 0,4 & 0,6094 & 0,0064 & 0,0046 & MEMENUHI \\
\hline
\end{tabular}

Dari perhitugan pada tabel 3, dapat disimpulakan terdapat 36 dari 137 saluran yang tidak mampu untuk menahan debit limpasan akibat curah hujan, yang menyebabkan area sekitar saluran ter yang tergenang air. Saluran yang tidak memenuhi debit limpasan tersebut ditunjukan dengan garis berwarna merah pada Gambar 3 .

\section{Faktor lain penyebab banjir}

Selain kapasitas saluran ada juga penyebab lain yaitu:

1. Mayoritas saluran yang ada di wilayah Taman Cibodas terdapat banyaknya sampah yang menghambat laju air yang mengakibatkan tersumbatnya saluran.

2. Mayoritas saluran memiliki sedimen pada bagian dasar saluran.

3. Wilayah Taman Cibodas Tangerang, khususnya Kelurahan Sangiang Jaya dilewati oleh sebuah kali yang menerima banjir bawaan sehingga membuat saluran yang ada wilayah ini meluap dan terjadi banjir. 


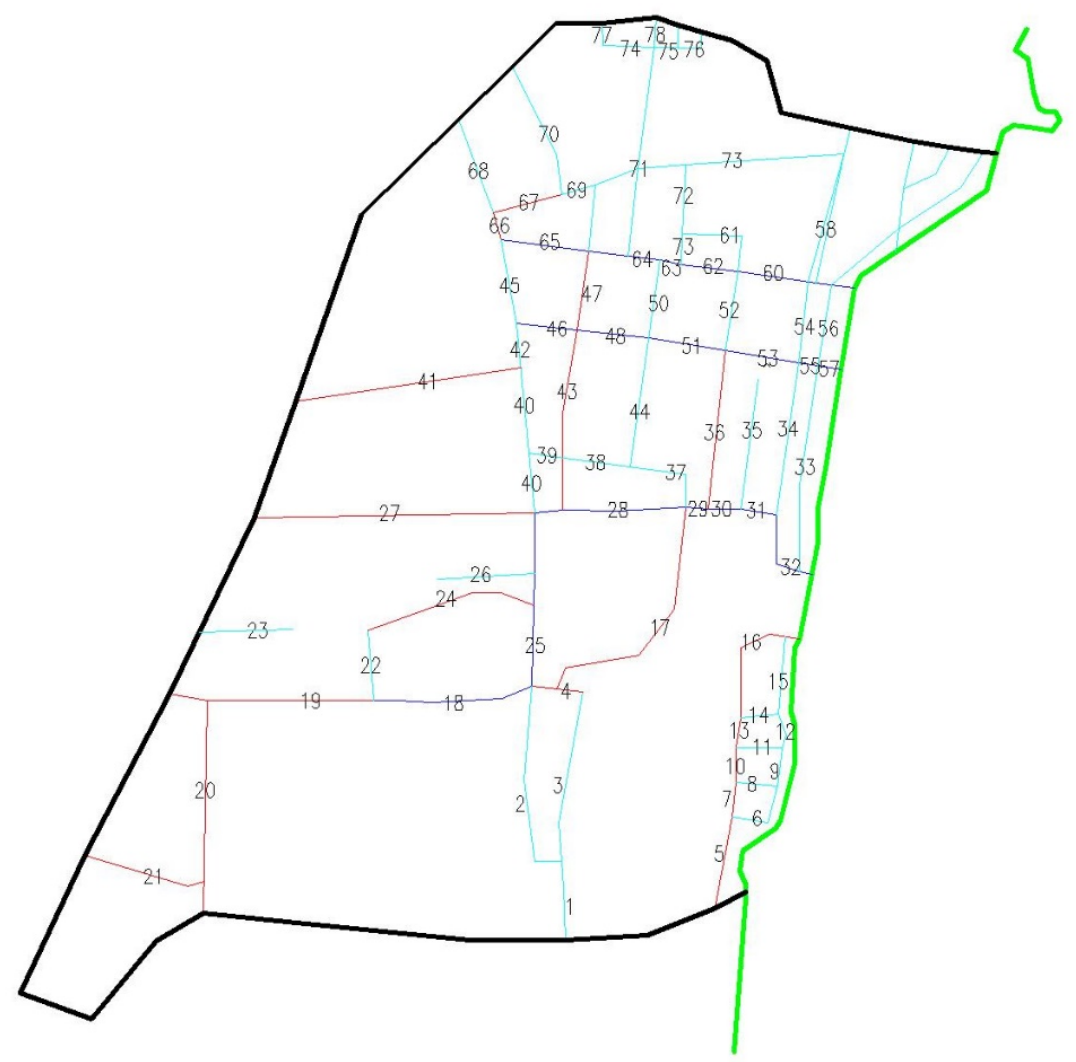

Gambar 3. Peta Saluran Taman Cibodas Tangerang

\section{Analisis saluran drainase rencana}

Dilakukan desain ulang untuk saluran eksisting yang tidak mampu menampung debit akibat curah hujan yang ada dengan memperbesar lebar dan kedalam saluran, yang sebelumnya memiliki dimensi lebar 0,4 m dan kedalaman saluran 0,4 m menjadi lebar $0,8 \mathrm{~m}$ dan kedalaman saluran $0,8 \mathrm{~m}$.

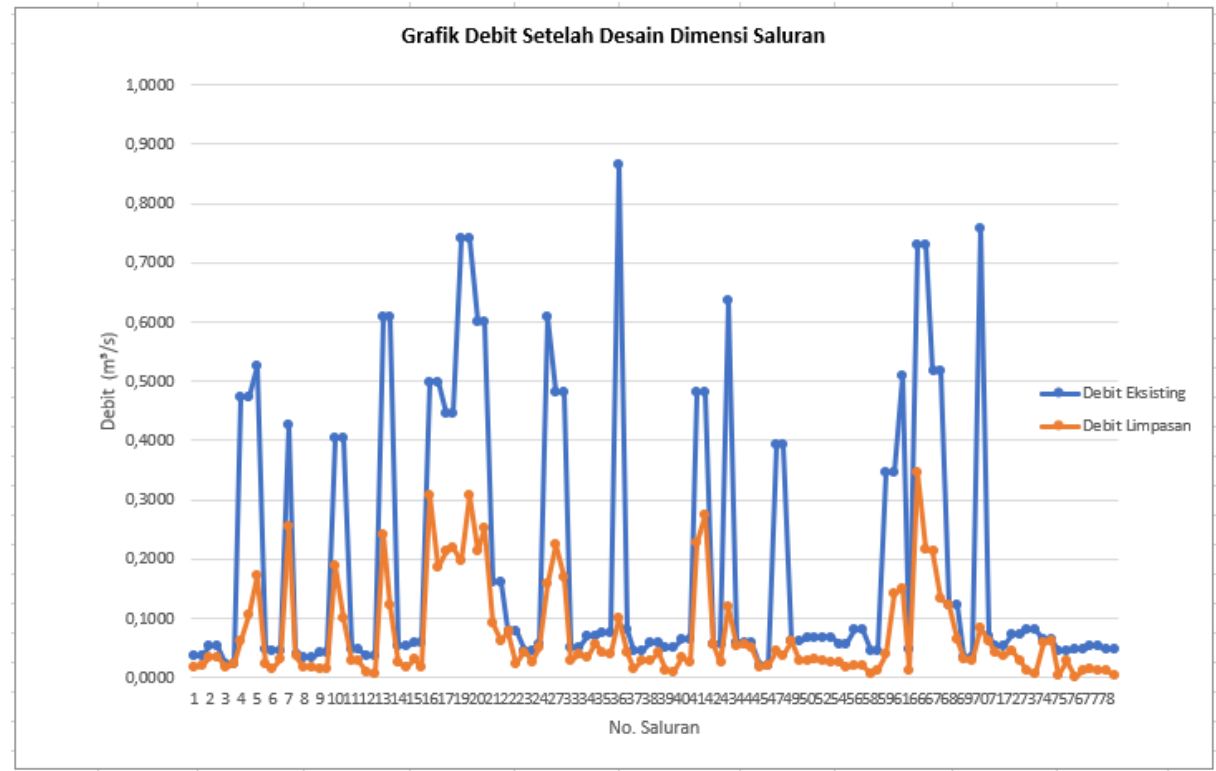

Gambar 4. Grafik Perbandingan Debit Limpasan dan Debit Eksisting Setelah Desain Dimensi Saluran 
Grafik diatas menunjukan perbandingan debit limpasan dan debit eksisting setelah saluran didesain ulang, dan bisa dilihat tidak ada lagi garis yang berpotongan satu sama lain yang menandakan setiap saluran yang ada mampu menampung debit limpasan akibat curah hujan selama periode 2 tahun.

\section{KESIMPULAN DAN SARAN}

\section{Kesimpulan}

Berdasarkan hasil penelitian yang sudah dilakukan, masi ditemukan beberapa faktor yang menyebabkan genangan air terjadi di Taman Cibodas Tangerang khusnya Keluarahan Sangiang Jaya, yaitu masi adanya 36 dari 137 saluran drainase yang tidak mampu menampung debit dari hujan yang terjadi, dan beberapa faktor lain yang membuat terjadinya genangan antara lain adalah masi banyaknya sampah yang yang menghambat saluran air yang ada disaluran dan sedimen pada dasar saluran.

Berdasarkan hasil penelitian yang sudah dilakukan, Solusi yang diberikan adalah melakukan desain ulang pada ke 36 saluran yang tidak mampu menampung debit hujan yang terjadi selama periode ulang 2 tahun, dengan hasil perhitugan desain saluran rencana yang sudah diteliti pada penelitian ini sebagai acuan, yaitu merubah dimensi saluran yang sebelumnya memiliki dimensi lebar $0,4 \mathrm{~m}$ dan kedalaman saluran $0,4 \mathrm{~m}$ menjadi lebar $0,8 \mathrm{~m}$ dan kedalaman saluran $0,8 \mathrm{~m}$, dan juga untuk melakukan permeliharaan saluran secara rutin agar saluran yang ada bersih dari segala sedimen dan sampah yang menghambat laju aliran air.

\section{Saran}

Berdasarkan hasil analisis yang sudah dilakukan, disarankan untuk peneliti selanjutnya menambahakan solusi lain seperti perhitungan pompa atau pembuatan sumur resapan sebagai penanggulangan banjir yang terjadi di Taman Cibodas Tangerang, dan peran penting kepala daerah dan organisasi pemuda setempat untuk memulai gerakan kepedulian terhadap lingkungan, agar masyarakat setempat menjadi sadar akan pentingnya kerbersihan lingkungan sehingga seluruh masyarakat yang ada bisa hidup dengan tertib dan aman.

\section{DAFTAR PUSTAKA}

Badan Pusat Statistik Kota Tangerang. “Kecamatan Cibodas Dalam Angka.” Kecamatan Cibodas (2018).

Badan Standardisasi Nasional. "SNI 2415:2016.” Tata cara perhitungan debit banjir rencana (2016).

—. "SNI 8456:2017." Sumur Dan Parit Resapan Hujan (2017).

Dinas Pekerjaan Umum dan Penataan Ruang Kota Tangerang. "Peta Sebaran Banjir dan Jaringan Drainase .” (2020).

Kementerian Pekerjaan Umum. "Penyelenggaraan Sistem Drainase Perkotaan.” 12/PRT/M/2014 (2014).

NKRI Post. "Perumahan Taman Cibodas Dikepung Banjir.” NKRI Post (2020).

Upono, Togani Cahyadi dan Rini Kusumawardani. "Pemilihan Distribusi Probabilitas Pada Analisa Hujan dengan Metode Goodness of Fit Test.” Jurnal Teknik Sipil dan Perencanaan, Nomor 2 Volume 18 (2016): 141143.

Yosef Haryono, Sp. Buku Kuliah Drainase. Jakarta: Fakultas Teknik Universitas Tarumanagara, 2016. 